\title{
Microwave-Assisted Enzyme-Catalyzed Reactions in Various Solvent Systems
}

\author{
Shan-Shan Lin, Chi-Hong Wu, Mei-Chuan Sun, Chung-Ming Sun, \\ and Yen-Peng Ho \\ Department of Chemistry, National Dong Hwa University, Hualien, Taiwan
}

\begin{abstract}
The work describes the accelerated enzymatic digestion of several proteins in various solvent systems under microwave irradiation. The tryptic fragments of the proteins were analyzed by matrix-assisted laser desorption/ionization mass spectrometry. Under the influence of rapid microwave heating, these enzymatic reactions can proceed in a solvent such as chloroform, which, under traditional digestion conditions, renders the enzyme inactive. The digestion efficiencies and sequence coverages were increased when the trypsin digestions occurred in acetonitrile-, methanol- and chloroform-containing solutions that were heated under microwave irradiation for $10 \mathrm{~min}$ using a commercial microwave applicator. The percentage of the protein digested under microwave irradiation increased with the relative acetonitrile content, but decreased as the methanol content was increased. These observations suggest that acetonitrile does not deactivate the enzyme during the irradiation period; in contrast, methanol does deactivate it. In all cases, the digestion efficiencies under microwave irradiation exceed those under conventional conditions. (J Am Soc Mass Spectrom 2005, 16, 581-588) (c) 2005 American Society for Mass Spectrometry
\end{abstract}

A dvances in mass spectrometric ionization methods, such as electrospray ionization (ESI) and matrix-assisted laser desorption/ionization (MALDI), make it possible to analyze complex biomolecules quite readily [1-5]. Tandem mass spectrometry (MS/MS) allows fragment ions to be generated from mass-selected precursor peptide ions, which, in turn, reveal sequence information for the peptide. The protein databases that are available in the public domain allow rapid identification of proteins by partial sequence analysis using tandem mass spectrometry; this process eliminates the need for complete protein sequence analysis [6-12]. The enzymatic cleavage of proteins into smaller peptide fragments is an important step to undertake before MS analysis for the characterization of protein structures.

To obtain detailed structural information, proteins are first subjected to proteolytic cleavage and then subjected to MS analysis of the resulting peptide mixture. This method of protein analysis is known as peptide mass fingerprinting. For a mass spectrometer capable of performing MS/MS analysis, the peptides are further sequenced by tandem MS before the identities of the proteins are analyzed. Efficient protein digestion requires production of peptides with a high coverage of protein sequence as well as fast digestion times. Generally, enzymatic digestions of proteins are carried

Published online March 5, 2005

Address reprint requests to Dr. Y.-P. Ho, Department of Chemistry, National Dong Hwa University, Hualien 974, Taiwan, ROC. E-mail: ypho@mail.ndhu.edu.tw out for several hours, or overnight, to generate sufficient amounts of peptides for analysis. To improve the efficiency of protein digestion, additives such as surfactants, organic solvents, and urea are often used to increase the proteins' solubilities and, thus, facilitate more-complete digestion [13, 14]. Recently, Gilar et al. reported that a novel acid-labile anionic surfactant solubilizes proteins and improves digestion rates without inhibiting the activity of trypsin or other common endopeptidases [13]. An alternative approach to improving the digestion efficiency is the use of microwave irradiation.

Microwave irradiation was recognized in the mid1980 s to be an efficient heating source for chemical reactions, where reactions that require several hours under conventional conditions can often be completed in a few minutes with very high yields and reaction selectivities [15-17]. To avoid the risk of potential explosions, reactions can be performed in open flasks by using solvents that have relatively high boiling points, such as acetonitrile and dimethyl formamide. The possibility of using milder and less-toxic reagents and solvents provide a further advantage of employing microwave technology. Many reports have been published on the beneficial effect of microwave irradiation in organic synthesis, e.g., for the preparation of heterocycles and for organometallic and rearrangement reactions [15, 18-21]. A number of review articles have appeared [22-26] that cover the underlying theory of microwave dielectric heating, the relevant dielectric parameters, and microwave-assisted organic reactions.

The use of microwave assistance in enzymatic chem- 
istry has been very limited. Chen and coworkers employed microwave irradiation to speed up the hydrolysis of peptides and proteins in a $6 \mathrm{M} \mathrm{HCl}$ solution in a sealed tube [27]. Bose et al. developed a microwaveenhanced modification of the Akabori reaction for the identification of the carboxy-terminal amino acid residue of peptides and the sequence of some peptide segments starting at the amino terminus [28]. Recently, Bose and coworkers also reported the use of microwave technology for the rapid and selective enzymatic digestion of several proteins in aqueous solutions [29].

Russell et al. reported enhanced proteolysis in organic-containing solvents [14]. They found that the analyzed proteins were denatured in mixed aqueous-organic solvents without sacrificing enzyme activity. Digestion in such solvent systems has the potential in the analysis of hydrophobic proteins. This work examined the possibility of applying microwave heating, using both domestic and commercial microwave systems, to further enhance the enzymatic digestion of proteins in organic solvents. Under rapid microwave heating, enzymatic reactions may be conducted in solvents that would, under conventional digestion conditions, render the enzymes inactive.

\section{Experimental}

\section{Materials}

$\alpha$-Cyano-4-hydroxycinnamic acid (HCCA) was obtained from Aldrich (Milwaukee, WI). Cytochrome $c$ (bovine heart), lysozyme (chicken egg white), myoglobin (horse heart), ubiquitin (bovine), trifluoroacetic acid, ammonium bicarbonate, and trypsin were purchased from the Sigma Chemical Co. (St. Louis, MO) and used without further purification. Acetonitrile and methanol were obtained in HPLC grade from Mallinckrodt Baker Inc. (Phillipsburg, NJ). Water was purified using a Milli-Q system (Millipore, Bedford, MA).

\section{Microwave Irradiation}

The enzymatic reactions were performed in a monomode microwave reactor (CEM Focused Microwave Synthesis, Model Discover, CEM Co., Matthew, NC). This microwave has an operating frequency of $2.5 \mathrm{GHz}$ and a maximum power of $300 \mathrm{~W}$. A noncontact infrared sensor, which monitors the temperature of the sample vial surface, is located beneath the reaction vessel. The set reaction temperature was maintained by using a sensor-controlled magnetron. The actual temperatures of reaction solutions were measured immediately with a thermocouple after microwave irradiation. We also used a domestic microwave system that operates at a maximum power of $600 \mathrm{~W}$; the power level was set at "medium", but we did not measure the real power output. There was no way to keep the reaction temperature constant. We could only measure the final tem- peratures of these reaction solutions with a thermocouple immediately after microwave irradiation.

\section{Enzymatic Digestion}

Proteins were treated with trypsin at a protease-toprotein molar ratio of 1:25. The concentration of the protein was set at $10 \mu \mathrm{M}$ in various solutions containing organic solvents. No reducing agent was added prior to the digestion. The $\mathrm{pH}$ of each solution was adjusted by adding acetic acid and ammonium hydroxide. The $\mathrm{pH}$ was not corrected for organic solvents. Digestion experiments were performed in a temperature-controlled water bath or in the microwave reactors.

\section{Mass Spectrometry}

MALDI spectra were acquired using an Autoflex timeof-flight mass spectrometer (Bruker Daltonic, Bremen, Germany) equipped with a 337-nm nitrogen laser (10 $\mathrm{Hz}$, 3-ns pulse width). Spectral data were obtained in the linear mode with an acceleration voltage of $25 \mathrm{kV}$. Each mass spectrum was derived from 50 summed scans. HCCA was used as a MALDI matrix, which was prepared by dissolving HCCA in a solvent mixture of acetonitrile and $0.1 \%$ TFA (2:1) at a concentration of ca. $50 \mathrm{mM}$. The MS analysis of each protein digest was conducted immediately after the enzymatic reaction. An aliquot of the sample solution $(0.5 \mu \mathrm{L})$ was mixed with an equal volume of the matrix solution and then applied on the target plate and dried before MALDI-MS analysis.

\section{Results and Discussion}

\section{Microwave-Assisted Trypsin Digestion}

The enzymatic reactions in various solvent systems were investigated. Figure 1 presents the MALDI mass spectra of the tryptic fragments of myoglobin obtained classically [Figure $1 \mathrm{a}^{\circ}{ }^{\circ}$ in $^{\circ}$ water $^{\circ}\left(\mathrm{pH}^{\circ} 8\right)^{\circ}$ at ${ }^{\circ} 37^{\circ} \mathrm{C}^{\circ}$ for ${ }^{\circ} 6^{\circ} \mathrm{h}$ ]

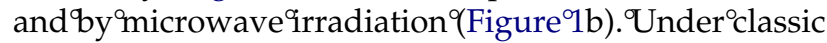
heating ${ }^{\circ}$ Conditions $^{\circ}\left(\right.$ Figure $\left.^{\circ} 1 \mathrm{a}\right)$, the $^{\circ}$ digestion ${ }^{\circ}$ percentage was $96 \%$. Digestion efficiency is defined as the ratio of the intensity of the most abundant peptide fragment ion to that of the undigested protein ion. The calculation assumes that the ionization efficiencies for peptide and protein ions are the same. Although this assumption is very approximate, this concept of efficiency is useful only in comparing digestion efficiencies with and without microwave irradiation. Notably, we conducted the enzyme reactions in a solution whose $\mathrm{pH}$ was adjusted by adding small amounts of ammonium hydroxide and acetic acid. Although the use of buffers such as ammonium bicarbonate to maintain a stable $\mathrm{pH}$ is important for enzyme-catalyzed reactions, buffers somewhat degrade the MALDI and ESI signals. Accordingly, an attempt was made to use only minimal amounts of acid and base in adjusting the $\mathrm{pH}$. The almost unbuffered 


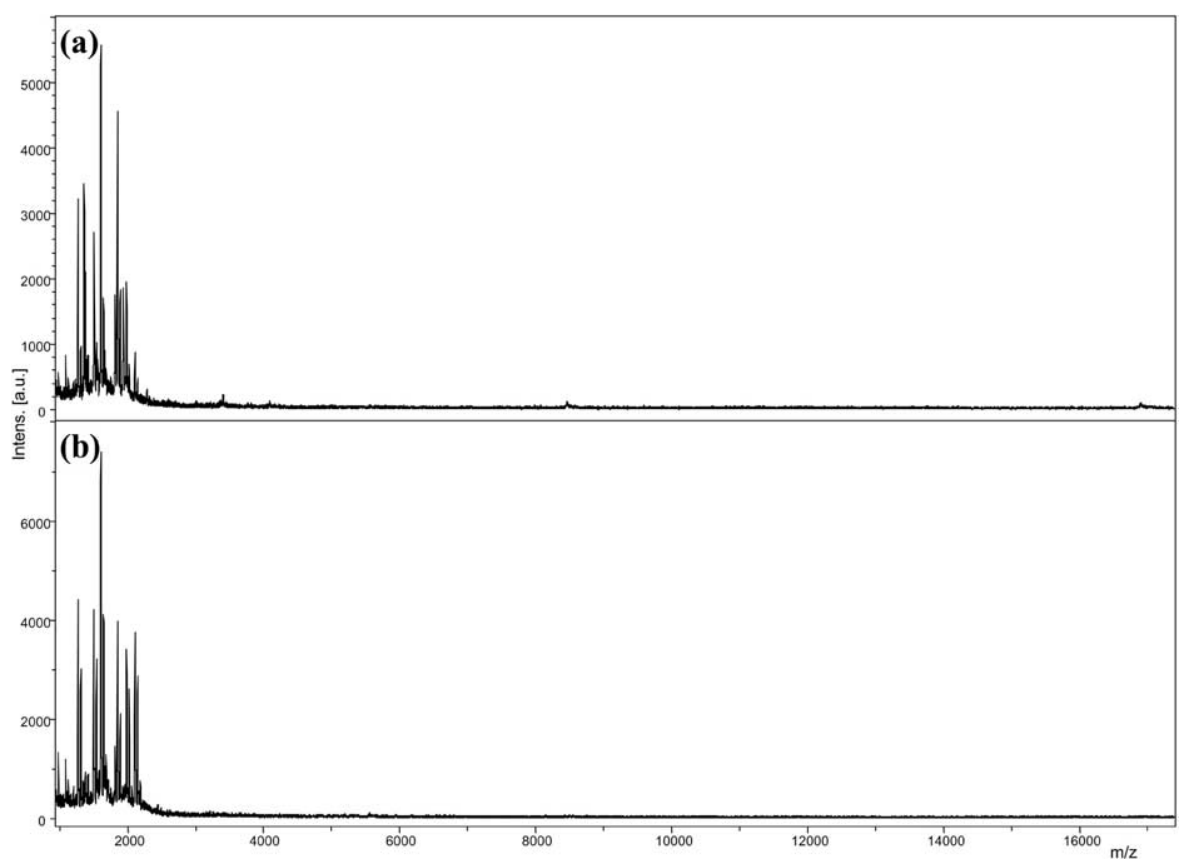

Figure 1. MALDI mass spectra of the tryptic fragments of myoglobin obtained in water ( $\mathrm{pH} 8)$ following digestion (a) at $37^{\circ} \mathrm{C}$ for $6 \mathrm{~h},(\mathbf{b})$ under irradiation in a commercial microwave system for $10 \mathrm{~min}$ at $60^{\circ} \mathrm{C}$.

experiments were useful also in testing the feasibility of microwave-assisted reaction under such conditions. When the digestion was carried out with microwave irradiation, the ${ }^{\circ}$ digestion ${ }^{\circ}$ as $^{\circ}{ }^{\circ}$ omplete in $10^{\circ} \mathrm{min}$. Table

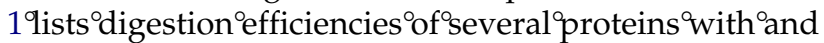
without microwave irradiation. The digestion of cytochrome $c$ is near completion under microwave irradiation and the efficiency is comparable to that without microwave irradiation. Lysozyme has disulfide bonds and is resistant to digestion, so a low digestion efficiency $(19 \%)$ is expected. Nevertheless, microwave irradiation still enhances the digestion efficiency (36\%). Ubiquitin is a tightly folded protein because it has a highly hydrophobic core and a high proportion of intramolecular hydrogen bonding. The protein's stable conformation makes it resistant to trypsin digestion. Microwave-assisted digestion of ubiquitin for $10 \mathrm{~min}$ yielded a somewhat better efficiency than the classic digestion method.

Microwave-assisted digestion may also be performed using an inexpensive domestic microwave. For instance, when the digestion of cytochrome $c$ was promoted by microwave heating using a domestic microwave system, low yields of peptides were observed ( $5 \%$ complete) after heating for $50 \mathrm{~s}$, to a temperature of only $38{ }^{\circ} \mathrm{C}$. The digestion efficiencies are $45 \%$ at $5 \mathrm{~min}, 92 \%$ at $10 \mathrm{~min}$, and $100 \%$ at $13 \mathrm{~min}$ (data not shown). Reaction times of $5 \mathrm{~min}, 10 \mathrm{~min}$, and $13 \mathrm{~min}$ corresponded to final temperatures of $54{ }^{\circ} \mathrm{C}, 76^{\circ} \mathrm{C}$, and $98^{\circ} \mathrm{C}$, respectively.

Next, the enzyme reaction proceeded in a 50\% methanol solution at $\mathrm{pH} 8$ with and without microwave irradiation. Figure $2 a^{\circ}$ presents ${ }^{\circ}{ }^{\circ}$ spectrum ${ }^{\circ}$ of myoglobin after its digestion by trypsin at $37^{\circ} \mathrm{C}$ for $6 \mathrm{~h}$. The digestion was completed so no undigested protein ions were detected. The digestion ran almost to completion (Figure $\left.{ }^{\circ} 2 b\right)^{\circ}$ when $^{\circ}$ the $^{\circ}$ reaction $^{\circ}$ was $^{\circ}$ assisted $^{\circ}$ by $^{\circ}$ microwave heating using a single-beam microwave system for ${ }^{\circ}$ onl ${ }^{\circ} 10^{\circ} \min ^{\circ}\left(60^{\circ} \mathrm{C}\right) .{ }^{\circ}$ Table ${ }^{\circ} 1^{\circ}$ summarizes ${ }^{\circ}$ the ${ }^{\circ}$ digestion efficiencies of the four proteins in a $50 \%$ methanol solution. Digestion efficiencies under microwave irradiation are better than or comparable to those obtained

Table 1. Digestion efficiencies (\%) of proteins in various solvent systems ( $\mathrm{pH} 8$ ) with and without microwave irradiation ${ }^{\mathrm{a}, \mathrm{b}}$

\begin{tabular}{lcccc}
\hline Proteins & $\mathrm{H}_{2} \mathrm{O}$ & $50 \% \mathrm{CH}_{3} \mathrm{OH}$ & $30 \% \mathrm{CH}_{3} \mathrm{CN}$ & $\begin{array}{c}\mathrm{CH}_{3} \mathrm{OH} / \mathrm{CHCl}_{3} / \mathrm{H}_{2} \mathrm{O} \\
(49 \% / 49 \% / 2 \%)\end{array}$ \\
\hline \hline Myoglobin & $100(96)$ & $94(100)$ & $94(100)$ & $29(0)$ \\
Cytochrome c & $96(100)$ & $95(15)$ & $70(14)$ & $39(0)$ \\
Lysozyme & $36(19)$ & $21(6)$ & $30(7)$ & $20(4)$ \\
Ubiquitin & $42(37)$ & $80(15)$ & $53(29)$ & $20(20)$ \\
\hline
\end{tabular}

aThe digestion efficiencies without microwave irradiation are indicated in parentheses.

${ }^{b}$ Digestion without microwave heating proceeded for $6 \mathrm{~h}$ at $37^{\circ} \mathrm{C}$. All the reactions under microwave irradiation, except for those in the experiments

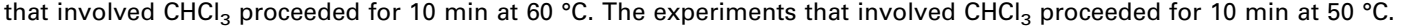




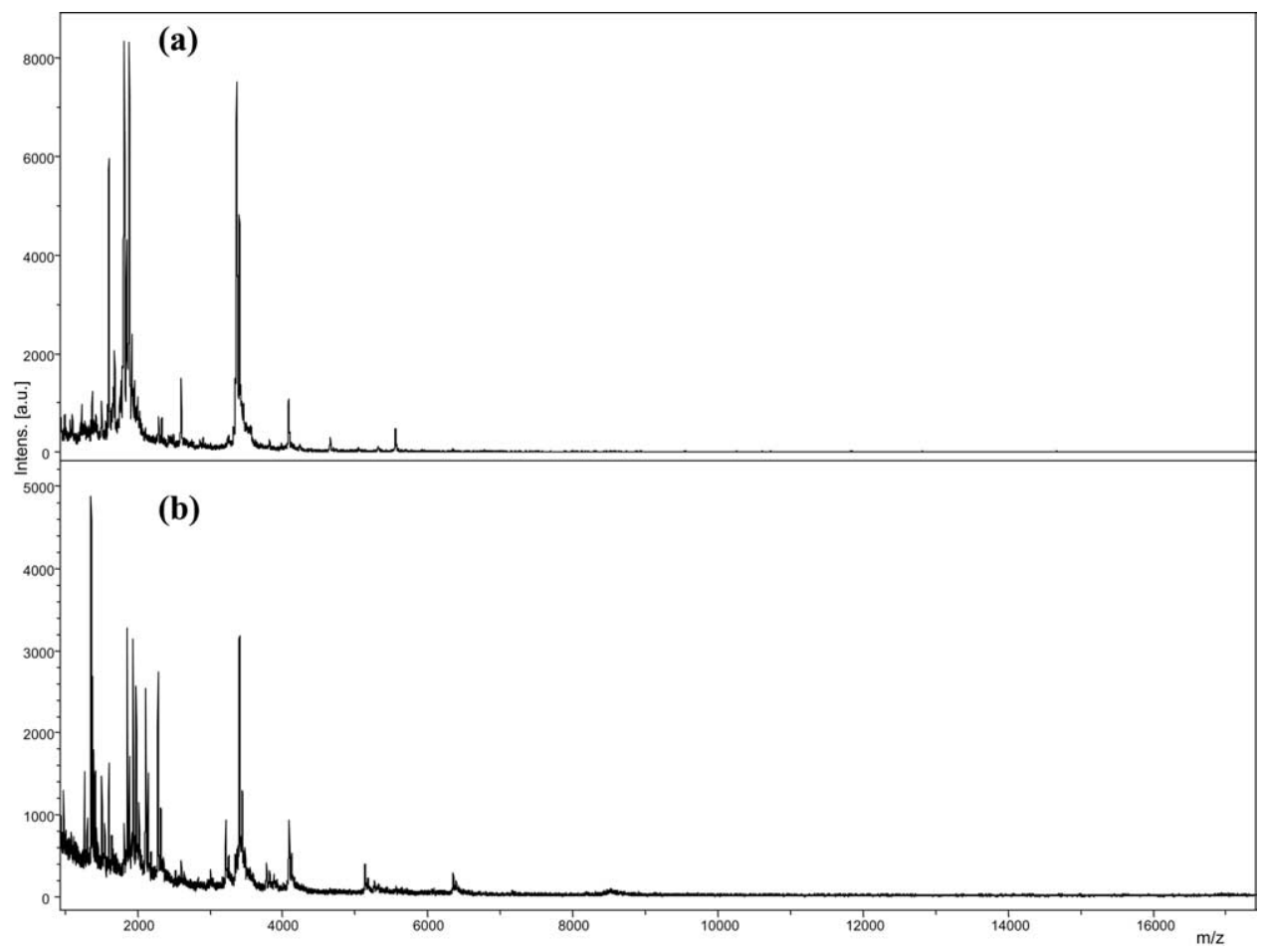

Figure 2. MALDI mass spectra of the tryptic fragments of myoglobin obtained in $50 \%$ methanol (pH 8) after digestion (a) at $37^{\circ} \mathrm{C}$ for $6 \mathrm{~h}$, (b) under irradiation in a commercial microwave system for 10 $\min$ at $60^{\circ} \mathrm{C}$.

without microwave irradiation. Methanol is a denaturant that seems to have two opposite effects on the digestion process. First, the denaturant unfolds the target protein and increases the digestion efficiency. Second, the denaturant may denature the enzyme and render it inactive. However, the enzyme activity has been reported to remain fairly constant in various organic-aqueous ${ }^{\circ}$ solvent $^{\circ}$ systems $^{\circ}[30] .{ }^{\circ}$ The $^{\circ}$ net $^{\circ}$ effect seems to favor digestion. However, a comparison of the digestion efficiencies of proteins in $\mathrm{H}_{2} \mathrm{O}$ and $50 \%$ methanol reveals that some efficiencies are higher in $\mathrm{H}_{2} \mathrm{O}$ and others are higher in 50\% methanol. The comparison is not very clear because the solubilities of the peptide fragments may not be the same in each solvent. In all cases, the fact that the efficiency is higher when microwave heating is used may indicate that fast heating and increased temperature accelerate the enzymatic reaction before the enzyme can lose all of its activity.

The digestion efficiencies of various proteins in $30 \%$ acetonitrile $(\mathrm{pH}$ 8) and methanol/chloroform/water $\left(49 \% / 49 \% / 2 \% ;{ }^{\circ} \mathrm{pH}^{\circ} 8\right)^{\circ}$ solutions ${ }^{\circ}$ were $^{\circ}$ examined $^{\circ}($ Table 1). ${ }^{\circ}$ Figure ${ }^{\circ}{ }^{\circ}$ shows $^{\circ}$ the ${ }^{\circ}$ mass $^{\circ}$ spectra ${ }^{\circ}$ associated ${ }^{\circ}$ with ${ }^{\circ}$ the trypsin digestion of cytochrome $c$ in $30 \%$ acetonitrile $(\mathrm{pH}$ 8) under and without microwave heating. The spectrum of the tryptic digest of cytochrome $c$ obtained under normal ${ }^{\circ}$ conditions $9\left(37^{\circ} \mathrm{C},{ }^{\circ} 6 \%\right.$; Figure $\left.3 a\right)$ includes many large peptide fragments and an abundance of undigested protein. This observation reflects the incomplete digestion of cytochrome $c$ in this solvent mixture. The digestion was improved dramatically when the single-beam microwave system was used as the irradiation $^{\circ}$ source $^{\circ}$ (Figure $\left.3 b\right) .^{\circ}$ This $^{\circ}$ is $^{\circ}$ also $^{\circ}$ true $^{\circ}$ for ${ }^{\circ}$ the proteins lysozyme and ubiquitin. The digestion of myoglobin is complete without microwave irradiation and nearly complete with microwave irradiation.

The enzyme is expected to lose much activity in a methanol/chloroform/water (49\%/49\%/2\%; pH 8) solution with such high percentage of organic solvent. The results indicated a very low abundance of tryptic fragments, or none at all. However, fast heating and increasing the temperature accelerated the enzymatic reaction and yielded satisfactory digestion when microwave heating was applied. The spectra reveal some large peptide fragments as well as the expected peptides after a reaction time of $10 \mathrm{~min}$ at a temperature of $50^{\circ} \mathrm{C}$. Figure $4^{\circ}$ displays the microwave-enhanced ${ }^{\circ}$ digestion of cytochrome $c$ in the chloroform-containing solvent. A little protein precipitate was observed in this solvent system. However, the comparison and conclusion are based on proteins that are soluble in the solvent, and the precipitation should not bias the conclusion.

\section{Effect of Solvent Composition on Digestion}

The enzymatic digestion process was studied by varying the proportions of the organic solvents and performing the reactions under neutral conditions while heating in a commercial microwave oven for $10 \mathrm{~min}$. The measurement of $\mathrm{pH}$ is inaccurate in organic sol- 


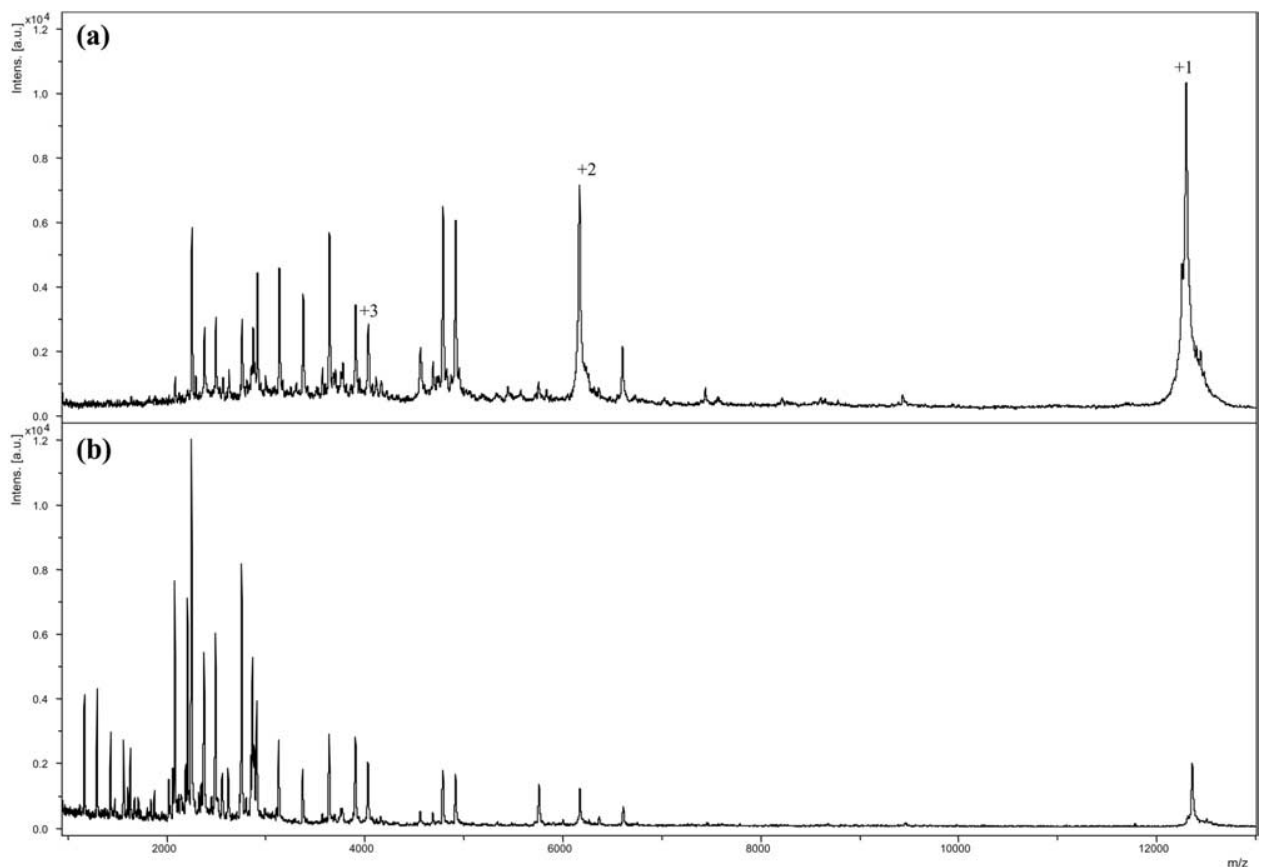

Figure 3. MALDI mass spectra of the tryptic fragments of cytochrome $c$ obtained in $30 \%$ aceonitrile $\left(\mathrm{pH}\right.$ 8) after digestion (a) at $37^{\circ} \mathrm{C}$ for $6 \mathrm{~h}$ and (b) under irradiation in a commercial microwave system for 10 min at $60^{\circ} \mathrm{C}$. The peaks marked $+1,+2$, and +3 correspond to the singly, doubly, and triply charged cytochrome $c$ ions, respectively.

vents, so the $\mathrm{pH}$ of the digestion solution was not adjusted to eliminate the effect of different acidities on digestion. ${ }^{\circ}$ Figure $^{\circ} 5 \mathrm{a}^{\circ}$ through ${ }^{\circ} \mathrm{d}^{\circ}$ present $^{\circ}$ the ${ }^{\circ}$ spectra ${ }^{\circ}$ of trypsin digests of cytochrome $c$ in water that contains 0 , 30,50 and $75 \%$ acetonitrile, respectively. The percentage of protein digested increased with the content of acetonitrile, which fact indicates that acetonitrile does not render the enzyme inactive. The digestion efficiency in pure $^{\circ}$ water $^{\circ}\left(\text { Figure }^{\circ} 5 a^{\circ}\right)^{\circ}$ is ${ }^{\circ}$ lower $^{\circ}$ than $^{\circ}$ the ${ }^{\circ}$ efficiencies obtained in acetonitrile-containing solvents. Two fac-

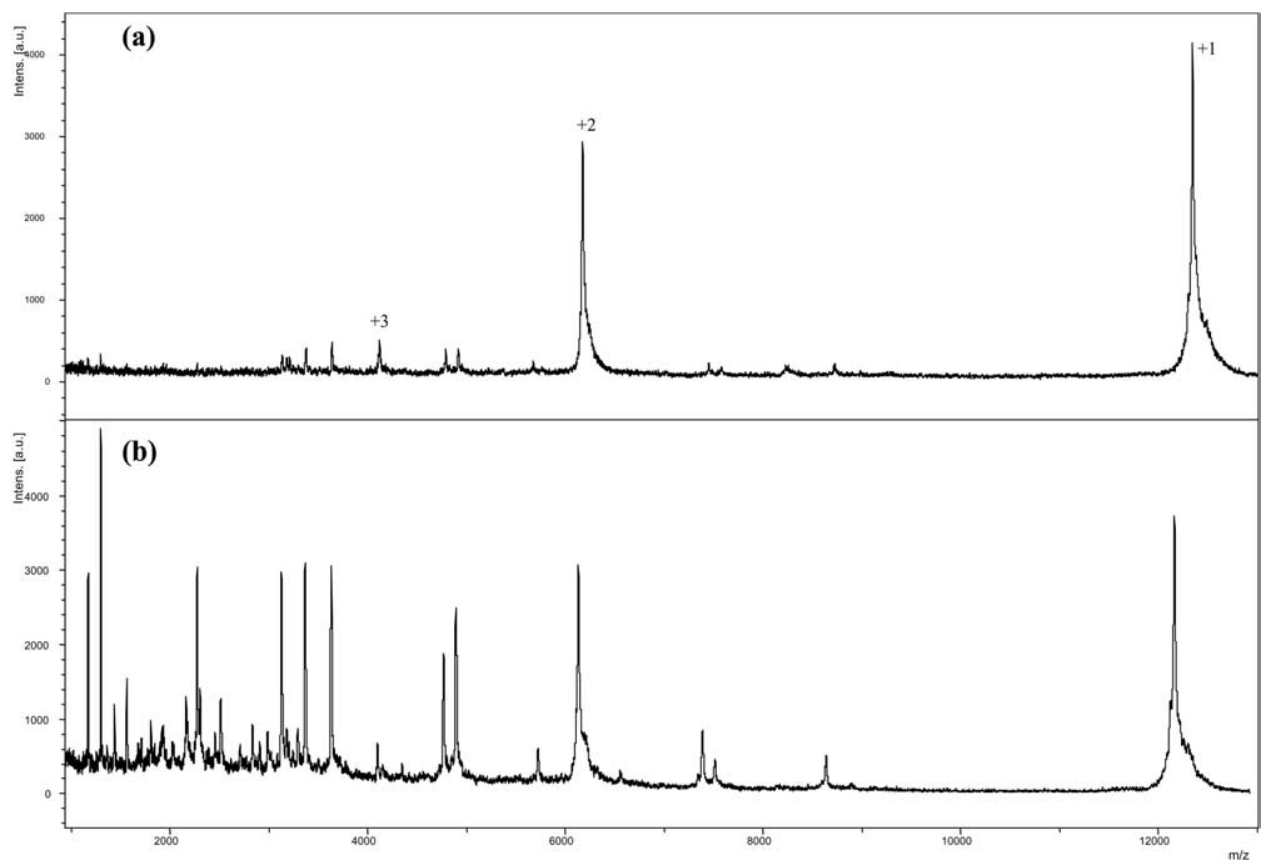

Figure 4. MALDI mass spectra of the tryptic fragments of cytochrome $c$ obtained in methanol/ chloroform/water $\left(49 \% / 49 \% / 2 \%\right.$; $\mathrm{pH}$ 8) after digestion (a) at $37{ }^{\circ} \mathrm{C}$ for $6 \mathrm{~h}$ and (b) under irradiation in a commercial microwave system for $10 \mathrm{~min}$ at $50{ }^{\circ} \mathrm{C}$. 


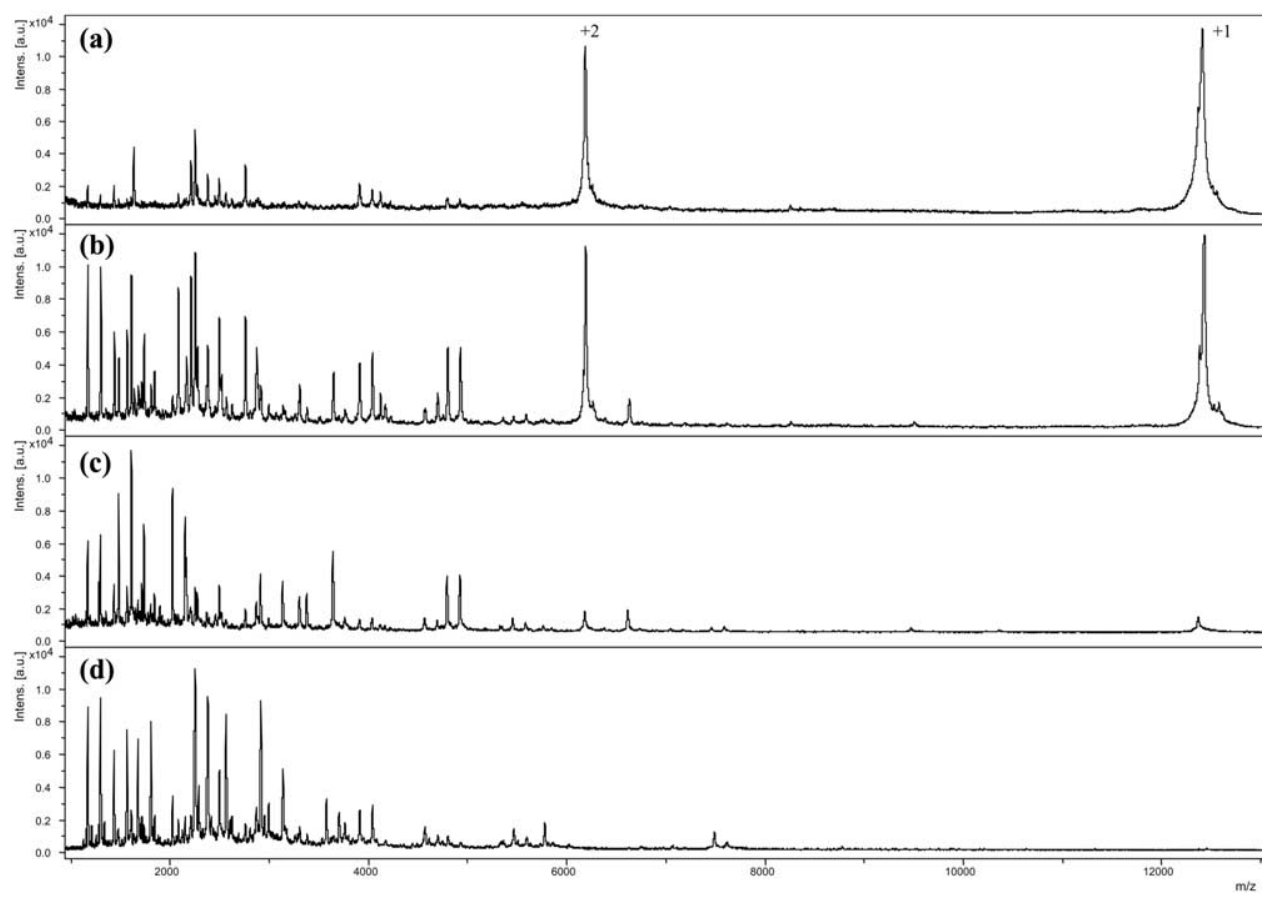

Figure 5. MALDI mass spectra of the trypsin-digested products of cytochrome $c$ obtained in (a) water and (b) 30, (c) 50, and (d) 75\% acetonitrile/water. The $\mathrm{pH}$ values of the solutions were not adjusted and the digestions were performed under microwave irradiation for $10 \mathrm{~min}$ at $60^{\circ} \mathrm{C}$.

tors may contribute to this finding: the denaturing of the protein in the acetonitrile-containing solvents may facilitate digestion, and the actual temperatures of the reaction in the solvents differ. Although the temperature in the microwave reactor was set to a constant value $\left(60{ }^{\circ} \mathrm{C}\right)$, the temperatures of the water, the $30 \%$ acetonitrile and the $75 \%$ acetonitrile solutions measured using a thermocouple immediately following microwave irradiation were 61,66 , and $69^{\circ} \mathrm{C}$, respectively. Thus, the higher temperatures may accelerate

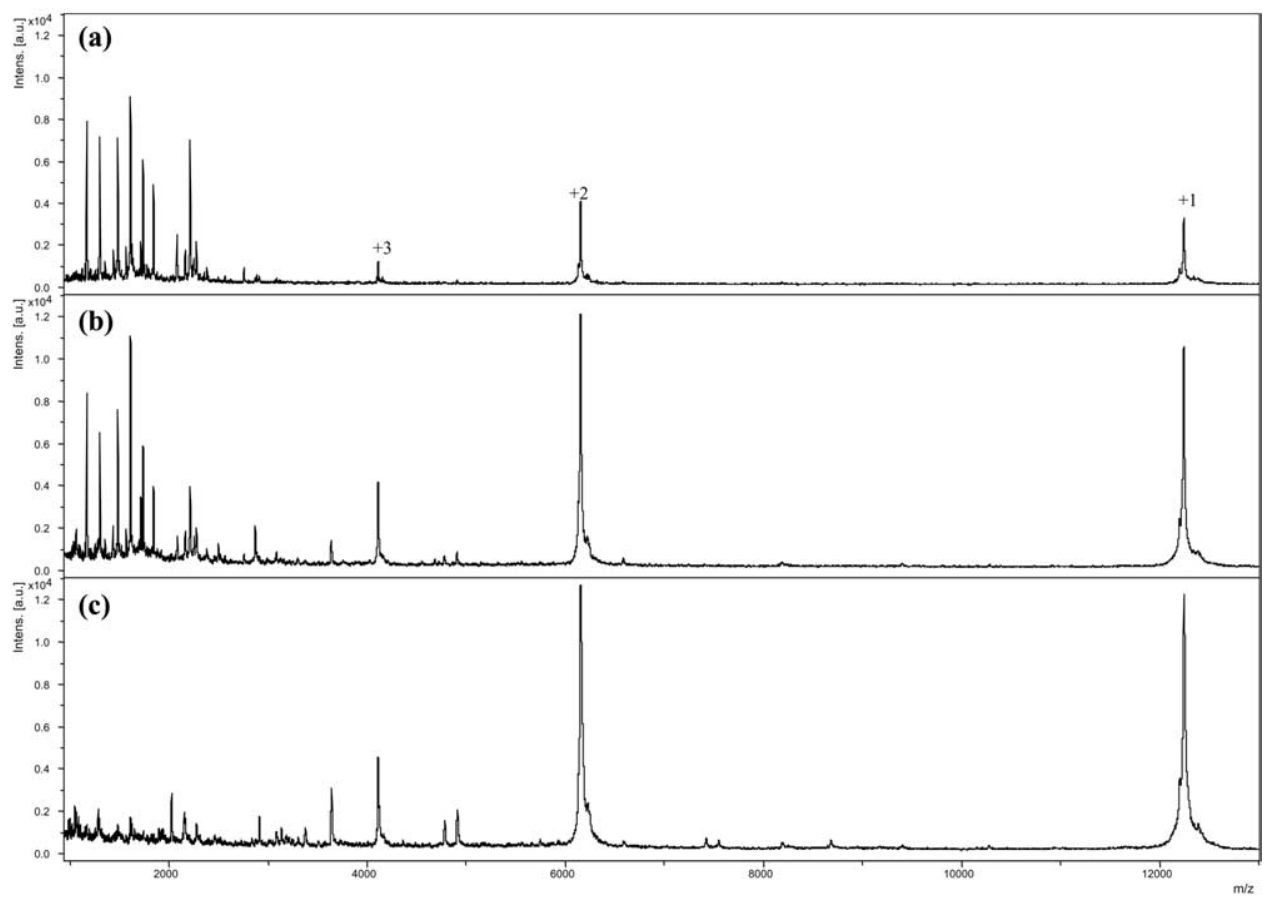

Figure 6. MALDI mass spectra of the trypsin-digested products of cytochrome $c$ obtained in (a) 30 , (b) 50 , and (c) $75 \%$ methanol/water. The $\mathrm{pH}$ values of the solutions were not adjusted and the digestions were performed under microwave irradiation for $10 \mathrm{~min}$ at $50{ }^{\circ} \mathrm{C}$. 
Table 2. Sequence coverages (\%) of protein digestion in various solvent systems with and without microwave irradiation ${ }^{\mathrm{a}, \mathrm{b}}$

\begin{tabular}{|c|c|c|c|c|}
\hline Proteins & $\mathrm{H}_{2} \mathrm{O}$ & $50 \% \mathrm{CH}_{3} \mathrm{OH}$ & $30 \% \mathrm{CH}_{3} \mathrm{CN}$ & $\begin{array}{c}\mathrm{CH}_{3} \mathrm{OH} / \mathrm{CHCl}_{3} / \mathrm{H}_{2} \mathrm{O} \\
(49 \% / 49 \% / 2 \%)\end{array}$ \\
\hline Myoglobin & $73(76)$ & $100(76)$ & $100(66)$ & $48(0)$ \\
\hline Cytochrome c & $89(73)$ & 79 (79) & $89(75)$ & $56(0)$ \\
\hline Lysozyme & $53(33)$ & $55(51)$ & $71(30)$ & $56(37)$ \\
\hline Ubiquitin & $100(62)$ & $100(100)$ & $86(64)$ & $67(45)$ \\
\hline
\end{tabular}

aThe sequence coverages without microwave irradiation are indicated in parentheses.

bThe experimental conditions are the same as those mentioned in Table 1

the enzymatic reaction. Determining the optimal temperature for the microwave-assisted enzyme reaction would be of interest, but the reaction is performed close to the boiling point of acetonitrile $\left(81.6^{\circ} \mathrm{C}\right)$, so further increases in temperature cause significant evaporation of the solvent and the precipitation of the protein. The precipitation during enzyme digestion reduces the intensities of the protein signals in the mass spectra and makes any comparison among spectra inaccurate. Similar results were obtained for myoglobin and ubiquitin.

Figure $^{\circ} 6 \mathrm{a}^{\circ}$ to ${ }^{\circ} \mathrm{c}^{\circ}$ show $^{\circ}$ the ${ }^{\circ}$ digestion $^{\circ}$ efficiencies $^{\circ}$ of cytochrome $c$ in 30,50, and 75\% methanol, respectively. The boiling point of methanol $\left(64.7^{\circ} \mathrm{C}\right)$ is lower than that of acetonitrile, so the reaction temperature in the microwave reactor is set to $50{ }^{\circ} \mathrm{C}$, which is $10^{\circ} \mathrm{C}$ lower than that in the previous set of experiments. The myoglobin and ubiquitin digestion exhibited the same trend. In contrast to the results obtained using acetonitrile/water solutions, the percentage of protein digested, and therefore, the enzyme's activity, declined as the methanol content was increased.

\section{Protein Sequence Coverage}

Table $^{\circ} 2^{\circ}$ summarizes $^{\circ}$ the ${ }^{\circ}$ sequence ${ }^{\circ}$ coverages $^{\circ}{ }^{\circ} f^{\circ}$ protein digestion in various solvent systems under and without microwave irradiation. The coverages using the peptides observed with masses higher than $\mathrm{m} / \mathrm{z}=1000$ were calculated; masses below $\mathrm{m} / z=1000$ were ignored because of interference with matrix signals. All of the data indicate that the sequence coverages under microwave irradiation exceed those without microwave irradiation. Russell et al. reported the various uses of mixed organic-aqueous $^{\circ}$ solvents ${ }^{\circ}$ in $^{\circ}$ protein $^{\circ}$ digestion $^{\circ}[14]^{\circ}$ and thermal $^{\circ}$ denaturation $^{\circ}$ prior $^{\circ}$ to $^{\circ}$ digestion $^{\circ}$ [31]. ${ }^{\circ}$ They found that the sequence coverages of the proteins in the presence of organic solvents exceed those in aqueous solution. ${ }^{\circ}$ The $^{\circ}$ results $^{\circ}\left(\text { Table }^{\circ}\right)^{\circ}$ from ${ }^{\circ}$ the ${ }^{\circ}$ classic ${ }^{\circ}$ digestion experiments obtained using organic solvents with 30\% acetonitrile and 50\% methanol are consistent with their results. Those authors also observed increased sequence coverages when the analyzed proteins were thermally denatured before they were digested. The present work combines both microwave-heating and organic solvents to denature proteins and increase the sequence coverages. Additionally, microwave-heating accelerates the digestion process and further improve the digestion efficiencies.

\section{Conclusions}

This work demonstrated that accelerated enzymatic digestions of several proteins, including myoglobin, cytochrome $c$, lysozyme, and ubiquitin can occur in various solvent systems when irradiated with microwaves. When rapidly heated by microwave irradiation, these enzymatic reactions can be carried out in solvents that, under conventional digestion conditions, render the enzymes inactive. The digestion efficiencies and sequence coverages are increased for the trypsin-catalyzed digestions in acetonitrile-, methanol-, and chloroform-containing solutions that were heated for $10 \mathrm{~min}$ using a single-beam microwave applicator. The proportion of protein digested under microwave irradiation increases with the acetonitrile content, indicating that acetonitrile does not render trypsin inactive. In contrast, the percentage of protein digested under microwave irradiation drops as the methanol content increases, suggesting a loss in the enzyme's activity in this solvent. In all cases, microwave irradiation increased the digestion efficiencies above those obtained under conventional conditions.

\section{Acknowledgments}

The authors thank the National Science Council of the Republic of China for supporting this research financially.

\section{References}

1. Hillenkamp, F.; Karas, M. Matrix-Assisted Ultraviolet Laser Desorption of Nonvolatile Compounds. Int. J. Mass Spectrom. 1987, 78, 53-68.

2. Karas, M.; Bachmann, D.; Hillenkamp, F. Laser Desorpton Ionization of Proteins with Molecular Masses Exceeding 10,000 Daltons. Anal. Chem. 1988, 60, 2299-2301.

3. Tanaka, K.; Waki, H.; Ido, Y.; Akita, S.; Yoshida, Y.; Yoshida, T. Protein and Polymer Analysis up to $m / z$ 100,000 by Laser Ionization Time-of-Flight Mass Spectrometry. Rapid Commun. Mass Spectrom. 1988, 2, 151-153.

4. Yamashita, M.; Fenn, J. B. Another Variation on the Free-Jet Theme. J. Phys. Chem. 1984, 88, 4451-4459.

5. Fenn, J. B.; Mann, M.; Meng, C. K.; Wong, S. F.; Whitehouse, C. M. Electrospray Ionization for Mass-Spectrometry of Large Biomolecules. Science 1989, 246, 64-71. 
6. Huang, P. Q.; Wall, D. B.; Parus, S.; Lubman, D. M. On-Line Capillary Liquid Chromatography Tandem Mass Spectrometry on an Ion Trap/Reflectron Time-of-Flight Mass Spectrometer Using the Sequence Tag Database Search Approach for Peptide Sequencing and Protein Identification. J. Am. Soc. Mass Spectrom. 2000, 11, 127-135.

7. Taylor, J. A.; Johnson, R. S. Sequence Database Searches via de Novo Peptide Sequencing by Tandem Mass Spectrometry. Rapid Commun. Mass Spectrom. 1997, 11, 1067-1075.

8. Jaffe, H.; Veeranna; Shetty, K. T.; Pant, H. C. Characterization of the Phosphorylation Sites of Human High Molecular Weight Neurofilament Protein by Electrospray Ionization Tandem Mass Spectrometry and Database Searching. Biochemistry 1998, 37, 3931-3940.

9. Tabb, D. L.; Saraf, A.; Yates, J. R. Gutentag: High-Throughput Sequence Tagging via an Empirically Derived Fragmentation Model. Anal. Chem. 2003, 75, 6415-6421.

10. Yates, J. R.; Eng, J. K.; Clauser, K. R.; Burlingame, A. L. Search of Sequence Databases with Uninterpreted High-Energy Collision-Induced Dissociation Spectra of Peptides. J. Am. Soc. Mass Spectrom. 1996, 7, 1089-1098.

11. McCormack, A. L.; Schieltz, D. M.; Goode, B.; Yang, S.; Barnes, G.; Drubin, D.; Yates, J. R. Direct Analysis and Identification of Proteins in Mixtures by LC/MS/MS and Database Searching at the Low-Femtomole Level. Anal. Chem. 1997, 69, 767-776.

12. Kapp, E. A.; Schutz, F.; Reid, G. E.; Eddes, J. S.; Moritz, R. L.; O'Hair, R. A. J.; Speed, T. P.; Simpson, R. J. Mining a Tandem Mass Spectrometry Database to Determine the Trends and Global Factors Influencing Peptide Fragmentation. Anal. Chem. 2003, 75, 6251-6264.

13. Yu, Y. Q.; Gilar, M.; Lee, P. J.; Bouvier, E. S. P.; Gebler, J. C. Enzyme-Friendly, Mass Spectrometry-Compatible Surfactant for In-Solution Enzymatic Digestion of Proteins. Anal. Chem. 2003, 75, 6023-6028.

14. Russell, W. K.; Park, Z. Y.; Russell, D. H. Proteolysis in Mixed Organic-Aqueous Solvent Systems: Applications for Peptide Mass Mapping Using Mass Spectrometry. Anal. Chem. 2001, 73, 2682-2685.

15. Lidstrom, P.; Tierney, J.; Wathey, B.; Westman, J. Microwave Assisted Organic Synthesis-A Review. Tetrahedron 2001, 57, 9225-9283.

16. Larhed, M.; Hallberg, A. Microwave-Assisted High-Speed Chemistry: A New Technique in Drug Discovery. Drug Discov. Today 2001, 6, 406-416.

17. Elander, N.; Jones, J. R.; Lu, S. Y.; Stone-Elander, S. Microwave-Enhanced Radiochemistry. Chem. Soc. Rev. 2000, 29, 239-249.
18. Suarez, M.; Loupy, A.; Salfran, E.; Moran, L.; Rolando, E. Synthesis of Decahydroacridines under Microwaves Using Ammonium Acetate Supported on Alumina. Heterocycles 1999, $51,21-27$.

19. Loupy, A.; Regnier, S. Solvent-Free Microwave-Assisted Beckmann Rearrangement of Benzaldehyde and 2-Hydroxyacetophenone Oximes. Tetrahedron Lett. 1999, 40, 6221-6224.

20. Olofsson, K.; Kim, S. Y.; Larhed, M.; Curran, D. P.; Hallberg, A. High-Speed, Highly Fluorous Organic Reactions. J. Org. Chem. 1999, 64, 4539-4541.

21. Orru, R. V. A.; de Greef, M. Recent Advances in SolutionPhase Multicomponent Methodology for the Synthesis of Heterocyclic Compounds. Synth. Stuttg. 2003, 1471-1499.

22. Nuchter, M.; Ondruschka, B.; Bonrath, W.; Gum, A. Microwave Assisted Synthesis-A Critical Technology Overview. Green Chem. 2004, 6, 128-141.

23. Gabriel, C.; Gabriel, S.; Grant, E. H.; Halstead, B. S. J.; Mingos, D. M. P. Dielectric Parameters Relevant to Microwave Dielectric Heating. Chem. Soc. Rev. 1998, 27, 213-223.

24. Gedye, R. N.; Wei, J. B. Rate Enhancement of Organic Reactions by Microwaves at Atmospheric Pressure. Can. J. Chem. 1998, 76, 525-532.

25. Langa, F.; DelaCruz, P.; DelaHoz, A.; DiazOrtiz, A.; DiezBarra, E. Microwave Irradiation: More Than Just a Method for Accelerating Reactions. Contemp. Org. Synth. 1997, 4, 373-386.

26. Loupy, A.; Petit, A.; Hamelin, J.; Texier-Boullet, F.; Jacquault, P.; Mathe, D. New Solvent Free Organic Synthesis Using Focused Microwaves. Synth. Stuttg. 1998, 1213-1234.

27. Chen, S.-T.; Chiou, S.-H.; Wang, K.-T. Enhancement of Chemical Reactions by Microwave Irradiation. J. Chin. Chem. Soc. 1991, 38, 85-91.

28. Bose, A. K.; Ing, Y. H.; Lavlinskaia, N.; Sareen, C.; Pramanik, B. N.; Bartner, P. L.; Liu, Y. H.; Heimark, L. Microwave Enhanced Akabori Reaction for Peptide Analysis. J. Am. Soc. Mass Spectrom. 2002, 13, 839-850.

29. Pramanik, B. N.; Mirza, U. A.; Ing, Y. H.; Liu, Y. H.; Bartner, P. L.; Weber, P. C.; Bose, M. K. Microwave-Enhanced Enzyme Reaction for Protein Mapping by Mass Spectrometry: A New Approach to Protein Digestion in Minutes. Protein Sci. 2002, 11, 2676-2687.

30. Simon, L. M.; Laszlo, K.; Vertesi, A.; Bagi, K.; Szajani, B. Stability of Hydrolytic Enzymes in Water-Organic Solvent Systems. J. Mol. Catal. B: Enzym. 1998, 4, 41-45.

31. Park, Z. Y.; Russell, D. H. Thermal Denaturation: A Useful Technique in Peptide Mass Mapping. Anal. Chem. 2000, 72, 2667-2670. 